\title{
Chinese Intellectuals and the Problem of Xinjiang
}

\section{Sebastian Veg}

\section{(2) OpenEdition}

\section{Journals}

\section{Electronic version}

URL: http://journals.openedition.org/chinaperspectives/4243

DOI: $10.4000 /$ chinaperspectives.4243

ISSN: 1996-4617

\section{Publisher}

Centre d'étude français sur la Chine contemporaine

\section{Printed version}

Date of publication: 1 July 2008

Number of pages: 143-150

ISSN: 2070-3449

\section{Electronic reference}

Sebastian Veg, «Chinese Intellectuals and the Problem of Xinjiang », China Perspectives [Online]

2008/3 | 2008, Online since 01 July 2011, connection on 21 September 2020. URL : http://

journals.openedition.org/chinaperspectives/4243; DOI : https://doi.org/10.4000/chinaperspectives. 4243

(c) All rights reserved 


\title{
Chinese Intellectuals and
}

\section{the Problem of Xinjiang}

\author{
SEBASTIAN VEG
}

I $\mathrm{t}$ is a common assumption that Chinese intellectuals, however critical of their government, its institutions, and its policies, are unreceptive to calls for greater self-government, much less independence, in China's autonomous regions, most notably Tibet and Xinjiang. ${ }^{(1)}$ While one could argue that Tibetan culture has, to an extent, exerted a form of attraction on critical minds in China in recent years (probably following a similar trend in the West), Uyghur culture and the political situation of Xinjiang do not seem present on their radar screens at all. An interesting exception is therefore represented by Wang Lixiong's book on Xinjiang, recently published in Taiwan, the title of which can be rendered as My Far West, Your East Turkistan. Wang Lixiong is no newcomer to the question, having devoted the past two decades to researching and reflecting on the place of "ethnic minorities" in China's political system, in particular in view of its possible democratisation, although he no longer holds any official "status" to carry out research since his much-publicised resignation from the Writers' Association in 2001.

Born in 1953 in Changchun into a family originally from Shandong, Wang Lixiong underwent rural re-education during the Cultural Revolution. His father, a Soviet-educated engineer, committed suicide (or was possibly killed) in 1968 (see p. $43^{(2)}$ ), and his mother was sentenced to re-education through labour. After returning from the country and working in a factory, Wang took part in the Democracy Wall movement in 1978 and settled in Beijing. In the 1980s he travelled around the Tibetan areas of the upper Yangtze and began writing on Tibet. After 1989, he published the "political fantasy" novel Huang Huo (Yellow Peril or Yellow Disaster) under the name Baomi (1991). (3) This novel, although fiction, contains all the themes that Wang has been interested in and has explored in his political writings: a looming demographic and energy crisis threatening the environment, nuclear war triggered by sensitive technologies falling into the wrong hands, and perhaps most importantly, the idea that the democratisation process could go horribly wrong and give rise to a fascist regime in China.

Wang remained active in the 1990s, creating the environmental association Friends of Nature (Ziran zhi you) in

1994, and researching and writing a book-length study of Tibet, published in 1998 under the title Sky Burial: The Fate of Tibet (Tianzang: Xizang de mingyun). In a follow-up to the book, he met the Dalai Lama (in the United States in 2001) for a series of talks, published in 2002 under the title Dialogue with the Dalai Lama (Yu Dalai Lama duihua). He has initiated two important petitions, one in favour of Tenzin Delek Rinpoche, a Tibetan lama accused of planning a terrorist attack in 2002, and another calling for an independent investigation and peaceful negotiations after the violent uprising in Lhasa in March 2008. During this period, his reflec-

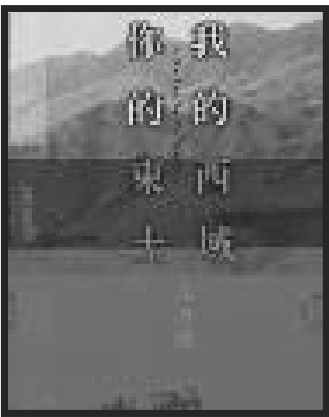

Wang Lixiong, Wo de Xiyu, ni de Dong Tu, Taipei, Dakuai Wenhua (Locus Publishing), 2007 tions on how to implement democracy in China also took a more conceptual turn in several of his essays: Dissolving power: a System of Gradual Election by Tiers (Rongjie quanli: Zhu ceng di xuan zhi, 1998), followed by Progressive democracy: China's Third Way (Dijin minzhu: Zhongguo de di san tiao daolu, 2004, expanded in 2006).

Wang Lixiong first began to study Xinjiang in 1999, when he travelled there to prepare research for a book along the lines of Sky Burial. He was arrested for photocopying an internal publication, stamped as "secret," on the Xinjiang Production and Construction Corps (the notorious bingtu-

1. In this paper, the name "Xinjiang" is used to refer to the Xinjiang Uyghur Autonomous Region (Xinjiang Weiwu'er zizhi qu) or XUAR, as this is the form used by Wang Lixiong (Uyghur groups usually prefer XUAR or East Turkestan). I would like to thank William Nee for his very helpful comments and criticism.

2. All page numbers in this format refer to Wang Lixiong, Wo de Xiyu, ni de Dong Tu, Taipei, Dakuai Wenhua (Locus Publishing), 2007. All translations are my own.

3. Baomi [Wang Lixiong], Huanghuo, Taipei, Fengyun shidai, 1991. English translation: Wang Lixiong, China Tidal Wave, trans. by Matthew Dillon, Honolulu, University of Hawaii Press, 2007. Extracts were published in French translation by Marie Holzman in Perspectives chinoises, no. 4 (June 1992), pp. 58-61. See also: Rémi Quesnel, "Wang Lixiong, an atypical intellectual," China Perspectives , n 50, Nov.-Dec. 2003. 
an), ${ }^{(4)}$ and attempted suicide in a high-security prison in Miquan before recanting and promising to collaborate in order to obtain his release. He recorded the incident in a short essay entitled Memories of Xinjiang (Xinjiang zhuiji), published in 2001 and reprinted as an introduction to the present volume. The introduction is followed by three other substantial sections. The first of these is a travelogue of Wang's four subsequent trips to Xinjiang between 2003 and 2006. It is followed by a long dialogue between Wang and a Uyghur intellectual named Mokhtar, with whom he shared a prison cell in 1999. The final part is comprised of three "Letters to Mokhtar," which conclude the conversation and sum up Wang's main points regarding the difficulties of Xinjiang independence. Wang Lixiong does not, therefore, write as an academic, nor does he give much background, even of a journalistic nature, but draws only on his conversations with various people in Xinjiang. This is inevitably problematic, especially as he does not speak Uyghur and has to rely on various friends to translate. This paper will therefore not attempt to bring much new material on Xinjiang into the discussion, but rather will assess how Xinjiang is viewed by a critical Chinese intellectual.

Wang's 1999 trip to Xinjiang was funded by an independent think tank run by a friend identified as Q, previously a member of the group of intellectuals counselling Zhao Ziyang. In the introduction, Wang describes buying a car in Ningxia and driving into Xinjiang with a Hui friend called A-Ke. After meeting with several contacts, including a Chinese official working in a government press agency and an old cadre in the bingtuan administration referred to as J, Wang, taking stock of their role in Xinjiang, ${ }^{(5)}$ requests and obtains from $\mathrm{J}$ an internal publication on the bingtuan, which he photocopies at a friend's office. Only afterwards does he realise that he has probably been followed all along by plainclothes police, and that the notes and interview log he has left openly in his hotel rooms have probably been thoroughly checked and read. As they are leaving Xinjiang, when Wang and A-Ke stop for the night in Hami, their car is confiscated under a pretext, and they are kept waiting until the commanding officer arrives from Urumchi. Wang is then formally accused of crimes against state security and imprisoned. After attempting suicide, he is taken to a hospital, then transferred to a high-security prison in Miquan, where he shares a cell with a Han prisoner accused of economic crimes ("Uncle Chen"), and a Uyghur prisoner arrested in Beijing for organising a demonstration protesting discrimination (Mokhtar). ${ }^{(6)}$ Finally, he agrees to sign the detailed statement of "collaboration" he is offered, includ- ing a promise not to contact any other security services (including the Beijing Public Security Bureau), thinking that this will at least enable him to take care of some family matters and do away with some compromising documents before handing himself in again. On this occasion, he even pokes fun at the Chinese Communist Party (CCP) for its "worship of the written word" (wenzi chongbai): "As though when something has been written down it automatically becomes the truth and can no longer be changed."

In the form of memories of prison conversations with Mokhtar, Wang Lixiong sketches out a preliminary analysis of the "Xinjiang problem," which he believes has entered a phase of "Palestinisation." He begins with some anecdotal examples of what he calls the Han "colonial attitude," citing the resistance to "Urumchi time" (7) among local Hans, and their worship of Wang Zhen (1908-1993), Party secretary of Xinjiang from 1949 to $1955 .{ }^{(8)}$ While in Mao's times all "nationalities" were submitted to equal oppression, Wang concludes that since the 1990s, which he isolates as a turning point, Uyghurs feel they have not benefited from the same treatment as the Han. After 1989, the Centre adopted a "nip all destabilising elements in the bud" policy (Ba yiqie bu wending de yinsu xiaomie zai mengya zhuangtai, p. 66), and increasingly resorted to pan-Chinese nationalism, strengthening the sympathies of Xinjiang's Han population, but increasingly alienating Uyghurs. Wang writes:

I have always been surprised at the government's wishful thinking in believing it could merge China's 56 nationalities into one under the artificial concept of "the Chinese nation" [Zhonghua minzu], and

4. The XPCC or bingtuan was originally a paramilitary group founded to absorb the remnants of the Republican army in Xinjiang in 1954. Tianshannet gives the 2003 population figure of the XPCC as 2,542,000 (13 percent of the population of the Xinjiang), of which 88 percent are Han Chinese. It is comprised of 14 divisions, directly administers five municipalities, runs two universities, a TV channel, and a daily newspaper, and has 11 publicly traded subsidiaries. http://www.aboutxinjiang.com/index.htm (12 August 2008).

5. J's assessment of the bingtuan's role is characteristic: "The function of the bingtuan is to guarantee that these 1.66 million km2 of land always retain the name 'China'!" (p. 21).

6. Wang Lixiong also notes that having learned the prison rules by heart, he carefully transcribed them on his computer once he returned to Beijing. One day, looking for the document on his computer, he discovers it has been erased (p. 53).

7. In 1980, the Xinjiang People's Congress decided to switch to "Urumchi time," two hours behind Beijing time, but abandoned the idea in the face of resistance by local Hans.

8. When Wang Zhen, State Vice-President and one of the "Eight Immortals" (influential in the 1989 crackdown) died, his ashes were scattered in the Tianshan mountains in accordance with his wishes. Uyghurs manifested their outrage by refusing to drink water from the Tianshan, which they believed had been sullied. Wang Lixiong notes that they manifest the same hostility toward Wang Lequan, whom they like to call Wang Shicai (a pun on Sheng Shicai, the warlord who ruled Xinjiang from 1933 to 1944). Various anecdotes illustrating the legendary brutality of Wang Zhen and Sheng Shicai are noted on p. 125. 
make them face the outside world with an identical outlook. (...) On the contrary, each nationality can also use nationalism for its own goals, strengthen its internal cohesion through nationalism, and justify separatism and independence in its name." (p. 59-60)

Wang shares the view of a nationalist or at least culturalnationalist revival in Chinese political discourse, initiated by Deng Xiaoping and reinforced after 1989. One may note that the main themes of this discourse $(5,000$ years of history, the "humiliation" of the Opium War and imperialism, anti-Japanese feelings) are not particularly conducive to appropriation by other ethnic groups, and indeed are sometimes downright detrimental (e.g., the emphasis on the Qing empire and the civilisation it purportedly brought to frontier regions such as Xinjiang). In this sense, Wang believes that the "Xinjiang problem" is largely a "selfffulfilling prophecy" (p. 61) in which an important role was played by the famous yet still mysterious "Document No. 7" issued in March 1996, the first to conflate separatism with "illegal religious activity." In this situation of mutual distrust, all efforts to stimulate the economy, no matter how profitable, were inevitably seen as colonialism. And in fact, Wang concludes that Han inhabitants of Xinjiang were able to reap an overwhelming share of the benefits. New Han farmers took over the land from Uyghur farmers, effectively colonising Xinjiang's agriculture. From 1990 to 2000, according to official statistics, the Han population in Xinjiang increased by 1.8 million people, or over 30 percent.

\section{Observations from the field}

Wang Lixiong subsequently returned to Xinjiang twice in 2003 (summer and fall) and twice in 2006 (spring and summer), and conducted a series of long interviews with Mokhtar in his hometown of Aksu from April to October 2006. He reports on deepening urban segregation and growing nepotism and corruption, highlighting the monopoly on mineral water held by Party Secretary Wang Lequan's ${ }^{(9)}$ son-in-law. Aksu is entirely in Wang Lequan's hands: the taxis of Aksu must join his son-in-law's corporation or face the non-renewal of their licenses (p. 193), and all electric poles are imported from a friend's company in Shandong (Wang Lequan is a Shandong native). The vice-mayor who must approve all real estate projects is himself a real estate developer from Wenzhou, and reserves the most lucrative projects for himself; returning to Aksu in 2006, Wang Lixiong finds that everything has been torn down and rebuilt in "Wenzhou style" (p. 194).
Wang goes on to highlight three main aspects of Xinjiang's socio-political system: the colonial economy and control of resources by Han officials, the education system, and more generally the politics of cultural uniformisation.

\section{Colonialism}

The bingtuan are characteristic of what Wang calls the colonial economy of Xinjiang. Entirely controlled by Han officials, they exert severe pressure on cotton prices, forcing impoverished farmers to sell cotton below market price for the benefit of the bingtuan system. Wang concludes that the system has no economic efficiency, and its continued existence is only justified to keep paying the pensions of its 430,000 retired workers, and more particularly as a rampart against "instability." (10) Thus, most of the interviewees he speaks to clearly believe that the subsidies Xinjiang receives from the Centre do not make up for the cheap "exports" Xinjiang delivers to Eastern China. A friend called $\mathrm{Z}$ in Urumchi points out that Xinjiang's natural gas is sold for the same price in Shanghai as in Xinjiang: the government thus appropriates Xinjiang's natural resources without offering any form of reparation for the pollution and environmental impact of resource exploitation (p. 246). Similarly, a farmer near Yengisar points out that electricity costs 0.85 $\mathrm{RMB} / \mathrm{KWh}$, which is double the price in Beijing (p. 136). This feeling of exploitation and disenfranchisement is compounded by the monopoly of positions of responsibility exercised by Han officials, ${ }^{(I I)}$ who manipulate village elections, use their positions to extend advantages to their family and friends, and devise projects that are incomprehensible to

9. Politburo member Wang Lequan became deputy Party secretary for Xinjiang in 1992 and acting secretary in 1994, and has served as full Secretary since 1995, in violation of the official policy to rotate provincial secretaries at least every ten years.

10. Wang Lixiong quotes Zhang Qingli, then Commander (silingyuan) of the Xinjiang bingtuan: "As long as there are enemy forces in the world, as long as there are separatist forces agitating in Xinjiang, as long as there is religious extremism brewing, the bingtuan will continue to exist forever, long live the bingtuan!" (p. 109). Zhang has now become notorious for his comments as Party secretary of the Tibet autonomous region, describing the Dalai Lama as "a jackal in Buddhist monk's robes and an evil spirit with a human face and the heart of a beast" in March 2008. Wang Lixiong specifically quoted this sentence in his petition calling for an independent investigation in Tibet, as an example of "Cultural Revolution language." See "Twelve Suggestions for Dealing with the Tibetan Situation, by Some Chinese Intellectuals," The New York Review of Books, vol. 55, no. 8 (15 May 2008), http://www.nybooks.com/articles/21379.

11. Wang gives three examples: in a village near Aksu without any Han inhabitants, most cadres are Han; a sports teacher in Aksu describes his school, in which there is not a single Han pupil but all cadres are Han, and the principal is the mistress of a high official (p. 203); in Subash, there are no Han inhabitants in the village, but the Party secretary is Han (p. 231). This monopoly of power positions by Han is borne out by research: Nicolas Becquelin's analysis of the 2000 Xinjiang Yearbook indicates that all 124 Party secretaries at prefecture, municipal, and county levels are Han. "Staged Development in Xinjiang," China Quarterly, no. 178 (June 2004), p. 363. 
local farmers (p. 139). Mokhtar underlines that in a situation in which all local officials are Han, their distribution of land leases always gives preferential treatment to their family, friends and people from Eastern China, while the local population feels progressively excluded from their land (p. 380). By way of contrast, Wang has pointed out in his research on Tibet that the key point of Zhao Ziyang's goodwill policy of the early 1980s was forcing Han cadres to step aside and hand over their positions to Tibetan cadres. ${ }^{(12)}$ Mokhtar emphasises that officials sent to Xinjiang have always promoted their own interests. Huge building projects are all carried out by companies from inner China who bring their own migrant workers, preventing any trickle-down for the local population from the "Great development of the West" (Xibu dakaifa) policy (p. 278). China has the largest highways in the world, he concludes: are they meant to develop Southern Xinjiang or simply to allow the army better control? (p. 278)

\section{Education}

The second point of interest to Wang is the school system, which is starkly divided between Uyghurs who learn Chinese ( $\min$ kao Han) and those who take their schooling in Uyghur (min kao min; see p. 55). Mokhtar's friend G points out that Uyghur teachers are routinely tested in Chinese (they are requested to take the HSK or Hanyu shuiping kaoshi), while Chinese teachers do not have to learn Uyghur. The system of "bilingual classes," in which only Uyghur literature is taught in Uyghur, is currently being generalised. Mokhtar outlines how "bilingual education," which began in 1997 as an experiment before being generalised in 2004, is progressively eliminating Uyghur teachers. In 2006, a cadre he picks up on the road confirms that under the new education policy implemented since 2000, 80 percent of teaching is in Chinese, and all official meetings are conducted in Chinese without translation, which compounds the Han monopoly on power. Mokhtar adds that the experiment has been extended to the university level, and that Uyghur-language professors will also soon be eliminated.

For Mokhtar, the Uyghurs are being assimilated (tonghua) through the increasingly Chinese school system. His friend points out that in Xinjiang University, over half the students are Han, although it was specifically established for minorities, and all classes must now be taught in Chinese (p. 213). The official goal of "three 60 percents" in the recruitment of students, workers, and soldiers (zhaosheng, zhaogong, zhaobing, p. 323) is therefore far from being met. Mokhtar underlines that minorities make up less than 10 percent of PLA (People's Liberation Army) troops stationed in Xinjiang, and Han likewise hold 70 percent of cadre-level positions (p. 324). Regarding university education, Han graduates can apply for universities in other provinces, while Uyghur graduates are only admitted to local universities; if they want to go to Eastern China, they must take two or three years of "preparatory classes" (yukeban) at Xinjiang University or Xinjiang Teachers' College.

For all these reasons, tensions in schools run high. Wang relates an anecdote about racist remarks in a classroom, ${ }^{(13)}$ concluding that colonial attitudes and racial discrimination are widespread inside the school system and taken for granted by teachers and Han students. Mokhtar also particularly resents the Han habit of requesting people to "be reasonable" (jiang daoli). For this reason, a frequent phenomenon is that parents who have gone through the min kao Han system send their children to min kao min because of the discrimination Uyghur children experience in Han language classes (Uyghurs call min kao Han students the "14" minority" of Xinjiang, because they are neither Han nor Uyghur $\left.{ }^{(14)}\right)$. Because of these political tensions, according to Mokhtar, 30 to 40 percent of Uyghur children in rural areas remain illiterate after their nine-year mandatory education (p. 280). Finally, schools are used as a channel to implement religious policy: children must go to school on Fridays during summer vacations (p. 133), and moustaches and beards are banned among teachers. Of course, all forms of religious activity are banned in schools (p. 232), which as elsewhere in China are an important channel for ideological indoctrination. A popular story tells how at one of the endless political discussion sessions at Xinjiang University, a professor says, "What do you mean by saying that Xinjiang has belonged to China for several thousand years? Several tens of thousands of years back, even before apes had changed into men, the Han apes came to Xinjiang to teach the Uyghur apes how to eat peaches and pick leaves!" (p. 311)

12. See Wang Lixiong, "Reflections on Tibet," New Left Review, no. 14, March-April 2002.

13. A teacher tells of a Han student who remarks in class that Xiangfei, the "Fragrant Concubine," a Uyghur princess sent to the emperor Qianlong, probably "smelled of mutton." When a Uyghur student subsequently asks the teacher to come and check whether he also "smells of mutton," the teacher requests his exclusion for improper behavior Finally, when the student's father, who is a cadre, comes to school and slaps the teacher in the face, the school backs down for fear of ethnic confrontation. (p. 205)

14. There are officially 13 minorities in Xinjiang. Wang expands on the unique position of these "min kao Han" students, some of whom choose to assimilate entirely into Han culture, while others reject it strongly, becoming Uyghur nationalists (p. 207). 


\section{Cultural assimilation}

As he travels, Wang Lixiong carefully records the places in which traditional Uyghur architecture and the way of life it encapsulates is being destroyed. In Keping in 2006, he describes how the local government has distributed a 3,000 RMB per household subsidy to build new houses, while the strict regulations for construction can only be met by spending at least ten times this amount. As a result, people build one room, leaving the construction to be completed when they have more money (p. 210). In Urumchi the "night market" and the "International Bazaar" are simply commercial ploys for the city cadres to make money. In 2006 Wang notes that not a single old building is left in Yining (p. 249): "Just as though a railway track had been built." Han inhabitants of Kashgar explicitly state that the destruction of old houses is designed to persuade Uyghurs to leave the old city. This phenomenon, which Wang calls "compoundisation" (xiaoquhua), and which is not peculiar to Xinjiang, is summed up in one sentence: "As for the loss of cultural specificities and of a special living environment, the profiteager officials are not interested" (p. 257). Wang, on the other hand, underlines that there should be no contradiction between preserving traditions and enjoying comfortable living conditions. He blames China's political system for creating incentives only for "image projects" (xinxiang gongcheng) to impress higher-ranking officials, and not to meet the aspirations of ordinary citizens.

\section{The nationalist view}

In his first conversation with Wang Lixiong, Mokhtar starts out by defining the "Xinjiang problem" as three-dimensional: national, religious, and socio-economic. He distinguishes between nationalists - mostly intellectuals who favour an independent nation-state (30 percent, according to Mokhtar); religious people who resent China's state atheism - mainly peasants (50 percent); and a relatively individualistic third group who are not interested in collective action, but only in their own best interest. Mokhtar believes that few people are happy with the present situation (5-10 percent) and that therefore most fit into one of the three groups (p. 265).

According to Mokhtar, relations between the Han and Uyghurs were good in the 1950s because the Han were so few (150,000 in 1956, of which 100,000 were PLA troops, p. 300), and they therefore had to learn Uyghur. Although there was some immigration from Gansu during the great famine of 1961-1962, and educated youths came from Shanghai during the Cultural Revolution, a balance was maintained. Nonetheless, beginning with the Anti-Rightist Campaign, which was particularly strong in Xinjiang, the Maoist state actively persecuted Uyghur culture: thousands of intellectuals were imprisoned, and the one-third that survived were not freed until the late 1970s. In 1961-1962, a violent campaign against "revisionists" also eliminated many Uyghur intellectuals who had been educated in the Soviet Union. During the Cultural Revolution, all Uyghur-language manuals as well as the Koran were burnt, and the new writing system was established in 1962. Muslims were frequently forced to raise pigs (p. 301).

For that reason, Mokhtar believes, at the time of Opening and Reform in the early 1980s, most intellectuals were willing to cooperate with the government and follow China's road to scientific and economic development. He situates the break occurring sometime in the 1990s, between the Baren uprising in $1990^{(15)}$ and the Ghulja uprising in $1997^{(16)}$ (which many people believe to have discredited peaceful resistance); Uyghurs suffered mass unemployment, while more and more Han immigrants moved to Xinjiang and took over their land. Mokhtar highlights that the bomb attack on a bus in Urumchi in 1997 was timed to coincide with the funeral ceremony of Deng Xiaoping (p. 356). At this point, most intellectuals had come to believe that China's development was incompatible with progress for the Uyghurs (p. 268). At the same time, the Chinese government became more and more nationalistic, promoting the idea of "Descendants of the Yellow Emperor" (Huang Yan zhi sun), and in 1996 issuing "Document no. 7," which clearly targeted "splittism" and "illegal religious activity." Mokhtar consequently believes it was the nationalist turn of the Chinese government that provoked Uyghur nationalism, compounded by the repressive policy of the late 1990s ("Beat down any head sticking out; do not slacken at any cost," or Lu tou jiu da, jue bu shou ruan). For the "unemployment generation," economic development has become synonymous with ethnic discrimination. Mokhtar gives the example of civil servant examinations: while Han people frequently

15. On 5 April 1990, large-scale fighting took place between insurgents who are generally associated with the East Turkestan Islamic Party and the PLA (more than 100 people are believed to have died). According to Mokhtar, this was triggered by the forced abortion of a three-month fetus to comply with birth control regulations. See Rémi Castets, "Opposition politique, nationalisme et islam chez les Ouïghours du Xinjiang," CERI Working Papers, no. 110 (October 2004), p. 25.

16. In February 1997, large numbers of young Uyghurs demonstrated in Ghulja (Yining). Many were arrested and some killed by a wave of repression by the Chinese authorities. See R. Castets, ibid., p. 29. 
complain that Uyghurs are "uneducated" (suzhi di), he argues that requirements for Uyghurs are actually much stricter. Many Han officials are former soldiers, and since the Great Development of the West policy, the government has encouraged graduates from professional middle schools (zhuanzhong biye) to come to Xinjiang as voluntary teachers, giving them civil servant status that Uyghurs have great difficulty obtaining. Mokhtar concludes that against a background of Chinese history, which he describes as a history of the assimilation of all peripheral peoples (p. 396), and in a present context of government-sponsored cultural integration and governmentencouraged migration into Xinjiang, the only solution is to advocate independence, which has become realistic in a postSoviet context. ${ }^{(17)}$ While he wants to put a stop to new "immigration," he believes that a peaceful mode of coexistence can be found with the Han population born and raised in Xinjiang (who, according to him, in fact also resent the new immigrants, p. 389). His model for the new state is an American-style liberal democracy, neither Arab dictatorship nor Islamic state (he believes the reforms needed to adapt Islam to modern society are stifled by Arab dictators). In response to Wang Lixiong's questions, he concedes that Uyghurs may have some sympathy for Osama Bin Laden, but they don't approve of him, because his attack on the Twin Towers is seen as directed against capitalism; according to Mokhtar, most Uyghurs, on the contrary, are for capitalism and against communism (p. 376). Mokhtar's model is a multiparty system with free elections, a separation between state and religion, and guarantees to safeguard the cultural rights of Chinese populations, such as in education. ${ }^{(18)}$

\section{Wang Lixiong and progressive democracy}

Wang Lixiong has some deep-set doubts, both about the practicality of independence as a goal for Xinjiang (due to the presence of a large Han population and their control of resources), but also about the type of democracy that Mokhtar advocates. In another text, he expresses his agreement with a draft Constitution prepared by a group of dissidents (Yan Jiagi and others), under which Tibet would receive a high degree of autonomy and the possibility to determine its own status after 25 years, while Xinjiang and Inner Mongolia would only be granted the status of autonomy through a two-thirds vote in the National People's Congress. ${ }^{(19)}$

While Wang insists that he doesn't mind one way or the other whether Xinjiang becomes independent, he emphasises alternatives to independence: the guarantee of genuine religious freedom, and the possibility of controlling labour migration by a work permit system that would apply to "cultural protection zones" (including Tibet), and which would serve to prevent desertification, degradation of the environment, and growing water shortages (p. 439). For Wang, democratisation in China, as opposed to a higher degree of autonomy, might be prone to nationalist manipulation and internal fracturing. He therefore calls for an embrace of the Dalai Lama's "Middle Way" of a high degree of autonomy within the framework of a federal China, going so far as to propose that the Dalai Lama become the chairman of a provisional government.

Nonetheless, his three final "letters to Mokhtar" reveal some of the deep-seated contradictions underpinning his thoughts on political reform in China. The first letter is devoted to the question of terrorism. A clear evolution can be noted with regard to Wang's first writings on Xinjiang in 1999, and also in comparison with his writings on Tibet. While his understanding of the September 11 attacks on the United States can at best be described as simplistic (an attack on America supported by Arab popular opinion because solidarity with Israel made America appear as the source of all evils), the conclusions he draws for China are in more of an apocalyptic mode, reminiscent of his sciencefiction novel Yellow Peril. Devoting an entire chapter to a fantasy description of a terrorist attack on the Three Gorges Dam by a lone diver with a nuclear backpack (p. 434), he insists that Beijing should learn from $9 / 11$ that even the greatest power in the world is not immune to a terrorist attack. It remains somewhat obscure why Wang Lixiong believes Xinjiang would be more likely to resort to terrorism than Tibet, and this whole concept seems steeped in scaremongering. ${ }^{(20)}$

In his second letter, he insists on Chinese nationalism. For Wang, China did not experience the nation-state model

17. In Mokhtar's view, Mohamed Imin persuaded his Uyghur "compatriots" not to push for independence after the Hotan uprising in 1931, on the grounds that the USSR would swallow an independent Uyghur state. Therefore it was only after the dissolution of the USSR that independence became possible (p. 378). There is much discussion of historical events at several places in the book, which unfortunately cannot be presented in detail here.

18. Mokhtar believes that, apart from cultural rights guaranteed by law, the fair representation of a Chinese minority in an independent Xinjiang can be ensured by reserving seats for them in the electoral system. He proposes that the overwhelmingly Han bingtuan should be transformed into counties (xian) electing delegates.

19. Wang Lixiong, "A Successive Multilevel Electoral System vs. a Representative Democratic System: Relative advantages for resolving the Tibet Question," http://wlx.middle-way.net/?action=show\&id=7 (1 June 2008). Wang Lixiong's page and the English translations posted on it no longer appear on Woeser's blog (12 August 2008). The text is available in Chinese ("Zhuceng dijin zhi yu minzhu zhi: Jiejue Xizang wenti de fangfa bijiao") on Wang Lixiong's new webpage : http://www.boxun.com/ hero/wanglx/6_1.shtml (19 September 2008). 
before 1911, and at that time its first formulation included Xinjiang and Tibet in Sun Yat-sen's "Republic of five races" (Han, Man/Manchu, Meng/Mongolian, Hui/Muslim, Zang/Tibetan). He adds that nationalism has always been an essential part of CCP ideology, and now the only portion remaining. ${ }^{(2)}$ For these two reasons he believes that democratisation would not necessarily solve the nationality question (p. 444). Whereas the Soviet constitution, no matter how misused, originally foresaw regional autonomy on paper by virtue of its federal nature, Wang asserts that no similar provision exists in the PRC Constitution, and that as a result, if China began unravelling, there would be no framework to stop the process from spreading to Guangdong or Shanghai. Conversely, he worries about an independent Xinjiang continuing to break down along ethnic lines into myriad autonomous micro-states, underlining that Uyghurs represent a majority of the population in only about one third of the territory concentrated in Southern Xinjiang, where there is no oil and resources. He wonders about the rights of the Hui (although one could easily object that there are Dungan populations in most of Central Asia), and highlights that Tibet, by contrast, is practically a mono-ethnic area. This is somewhat troubling, as in his articles on Tibet Wang argues against the viability of Tibetan independence, despite its ethnic homogeneity, on the grounds that the small Han elite controls the most productive sectors of the economy and the most dynamic groups in Tibetan society. ${ }^{(22)}$

Wang's assertion about the lack of a legal framework is in fact quite untrue: China's Law on Regional Ethnic Autonomy (Zhonghua Renmin Gongheguo Minzu quyu zizhifa), revised in 2001 and largely disseminated though a 2003 State Council White Paper on the Xinjiang Uyghur Autonomous Region (XUAR), could provide a legal framework for autonomy, even though it clearly remains a political fiction at the present time (as was the Soviet constitution). ${ }^{(23)}$ More largely, within the context of the international conventions ratified even by the present Chinese government, as well as other international declarations, a stable body of norms regarding minority rights and rights for indigenous populations would be available to guarantee either substantial autonomy for Uyghurs within China, or for Han within an independent Xinjiang.

Wang Lixiong seems to remain captive to conventional views in China that describe international covenants as instruments of power play: he describes them as merely a pretext for American or Western intervention in Xinjiang aimed at destabilising China, and quotes the theory of "precedence of human rights over sovereignty" or renquan gaoyu zhuquan. Finally, he concludes that even if Xinjiang were to become independent, it would soon be re-conquered, again reasoning in terms that are perhaps too exclusively determined by "realist" paradigms of international relations. In the same way, he concludes that the unravelling of the Soviet Union was "in the interest" (hesuan) of Russians, because Russia represented three quarters of the land but only half the population, while in China, the opposite is true: the Han are a majority in only 40 percent of the territory of the People's Republic, while they represent over 90 percent of population. The most worrying aspect here is probably that Wang Lixiong gives no positive reasons in favour of autonomy; he never mentions the benefits of economic integration, common language, or market opportunities, but only insists on a series of probably exaggerated dangers, and thus eschews the dispassionate discussion of advantages and drawbacks that he himself advocates.

His third letter deals with his system of proposed "progressive democracy" (dijin minzhu) and the implicit critique of liberal democracy it contains. Wang calls the latter "forum democracy" (guangchang minzhu, p. 457), and believes it can only exacerbate interethnic tensions, which will be fanned by the elite, a phenomenon not unknown in "mature democracies" (he cites support for the Iraq war). "Largescale democracy" (daguimo minzhu) will polarise political debate and lead straight to fascism (p. 460), as opinion leaders in Xinjiang will want to settle scores with China, the media will pour oil on the fire to make money, and the "masses," who love heroes and lofty speeches, will follow populists and opportunists. Nonetheless, he sees democracy as the key to resolving ethnic conflicts, the problem being not democracy itself but "large-scale democracy." Therefore, Wang goes over old ground by proposing a system of indirect elections, based on natural villages, in which votes would take place by household, each household selecting one representative (one wonders how women would fare in this system of representation), thereby allowing for direct

20. There are indeed many government reports on terrorist attacks in Xinjiang, but very few are independently corroborated, and many are contested by Uyghur groups overseas. An interesting example is the recent questioning of the August 2008 attack on military policeman in Kuqa. See Edward Wong, "Doubt Arises in Account of an Attack in China," New York Times, 29 September 2008.

21. In the first part of the book, Wang Lixiong goes so far as to contend that nationalism has entirely replaced ideology in the 1990s (p. 51).

22. Wang Lixiong, "A Successive Multilevel Electoral System vs. a Representative Democratic System: Relative advantages for resolving the Tibet Question," art. cit.

23. The Autonomy Law is available on http://www.gov.cn/test/2005-07/29/content 18338.htm. See also: Information Office of the State Council, "History and Development of Xinjiang," May 2003, http://news.xinhuanet.com/zhengfu/200306/12/content_916306.htm. 
deliberative democracy by consensus. The elected representative automatically becomes a voter on the higher level, and so on, preserving the direct and participatory nature of democracy (p. 464). In fact, this blueprint clearly reveals Wang Lixiong's misgivings about representation and vote by majority. ${ }^{(24)} \mathrm{He}$ favours consensus over voting, pointing out that all elections are problematic, even in the United States (the 2000 presidential election inevitably comes up), not to mention in a Tibetan village in which a majority of inhabitants are illiterate.

Although he writes that in this system policy decisions on various levels should not interfere, he gives no guiding principle, not even a philosophical one, to explain how responsibility should be divided. The implicit assumption is, in fact, that voters are not qualified to deal with any matters beyond their immediate experience, and that the only decisions taken on each level are those that directly affect the life of the constituency. "Regarding larger matters that go beyond the borders of their immediate experience, it is very difficult for the masses to gain a correct grasp" (p. 466). This is in fact a highly elitist system, the most worrying aspect of which is that it relies on the spontaneous generation of a social elite to foster democracy, rather than on an institutionalised system of checks and balances. Although Wang insists that this system will ensure that China does not break apart by guaranteeing both autonomy and cohesion (p. 468), one cannot help but wonder whether China and Xinjiang would not be better served at the outset by a full implementation of China's own Autonomy Law, to be completed by other guarantees of the rights of minorities as set out in international laws and norms. Interestingly enough, while he is so wary of representative democracy, Wang Lixiong entirely trusts his own electoral system to guarantee individual and collective rights by its intrinsic mechanisms rather than by formalised norms (p. 469).

For these reasons, although Wang Lixiong has gone further than most Chinese intellectuals in exploring the rights and claims of ethnic minorities and how they fit into the political problems of China as a whole, his newest book remains somewhat disappointing. It is true that he paints a sympathetic portrait of "ordinary Uyghurs," far removed from the usual clichés of official discourse, exoticism, or commonly repeated slurs - an important accomplishment that may act as a bridge towards even-minded ordinary Han Chinese citizens. But just as he portrayed Tibetans as prone to blindly following Maoism as a new religion during the Cultural Revolution, smashing their own temples and Buddhas, and then blindly reviling Mao when he proved not to have been a god after his death, ${ }^{(25)}$ his view of Uyghur intellectuals as influenced by terrorism and Islam seems excessively culturalist in relation to modern, secular Xinjiang. His analyses of several issues appear uninformed. Leaving aside academic research, he is particularly weak on government policy; an analysis of Hu Jintao's readily available 2005 speech to the State Commission on Ethnic Affairs could have yielded important insights: one of Hu's central tenets is that any form of increased autonomy remain subordinate to the "three inseparables." (26)

Nonetheless, Wang's openness to dialogue and public discussion of his ideas, without any taboos or prerequisites, is certainly an important step towards weaving the concerns of Uyghurs or Tibetans into the debate on the democratisation of China - taking into account, of course, that the present book cannot be published on the mainland. In this capacity, as also demonstrated by his March 2008 initiative on Tibet, Wang Lixiong is one of the closest examples of a public intellectual in China. In this context, his writings also demonstrate that, despite what the Chinese government publicly states, there is no consensus in China over the fact that no price is too high to ensure that the CCP remains the dominant force in Xinjiang or Tibet. His ideas may even trickle, gradually and windingly, to the corridors of power. Wang Lixiong opposes independence for both Xinjiang and Tibet, but his willingness to discuss practical measures such as migration restrictions or enhanced religious freedom also serves as a reminder that Chinese intellectuals are not necessarily Han nationalists. •

24. Interestingly, though perhaps not unsurprisingly, this type of institutional arrangement has been proposed by thinkers critical of both "Western democracy" and their own governments. To give two examples, the conservative revolutionary Zhang Binglin (18681936) favoured this type of system to avoid the "feudal" nature of parliamentary representation. Alexander Solzhenitsyn also advocated a similar arrangement based on traditional Russian zemstvo assemblies.

25. This is the object of the debate between Wang Lixiong and Tsering Shakyar. See Wang Lixiong, "Reflections on Tibet," art. cit., and the rebuttal: Tsering Shakyar, "Blood in the Snow," New Left Review, no. 15, May-June 2002. The gist of Tsering Shakyar's argument is that Mao-worship in Tibet was no more blind than elsewhere in China, and that traditional Tibetan society remained dynamic and changing despite its religious characteristics. Woeser also documents the importance of the Mao-cult among Tibetans in Shajie: Forbidden Memory: Tibet during the Cultural Revolution (Taipei, Dakuai wenhua, 2007).

26. The "three inseparables" (sange libukal) are: the Han cannot be separated from minorities, the minorities cannot be separated from the Han, and the minorities cannot be separated one from another. See: "Hu Jintao zai Zhongyang minzu gongzuo huiyi shang de jianghua" [Hu Jintao's Speech at the Central Nationalities Working Committee], May 27, 2005, http://politics.people.com.cn/GB/1024/3423605.html (12 August 2008). 